\title{
Coastal Dump Sites in the Lagos lagoon and toxicity of their leachate on brackish water shrimp (Palaemonetes africanus)
}

\section{*11AMAEZE, NNAMDI HENRY; ABEL-OBI, CHIBUEZE JACKSON}

\author{
Ecotoxicology Laboratory, Zoology Department, University of Lagos, Akoka-Yaba, Lagos, Nigeria
} Corresponding Author: amaezenh@gmail.com; +2347066302345

\begin{abstract}
An assessment of the coastal dumpsites and their impacts on shrimp mortality in the Lagos lagoon was investigated. The study involved a census of dumpsites in the major sections of the coastline associated with anthropogenic activities, followed by specific bioassay to determine the acute toxicity of leachates from one of the dump sites. Our investigations revealed that there were 8 major dumping localities with approximately 28 dumpsites generated mostly by deliberate efforts and in some cases by tidal activities which litter the coastline. The major dumping localities were Abule Eledu, Ebute Ilaje, Oworonshoki, Ibese, Offin, Off Ozumba Mbadiwe Road, Iddo and Okobaba. The largest number of dumpsites was recorded at Owonronshoki and Ibeshe, each with 19\% of the total dumps while the least number was recorded at Off Ozumba Mbadiwe Road (4\%). The major waste categories include fabrics (worn clothes), plastics, wood and wood shavings, glass, metallic objects as well as paper and packaging materials. The acute toxicity assessment of leachates from a dumpsite at Abule Eledu indicated moderate toxicity to brackish water shrimps (Palaemonetes africanus) with $96 \mathrm{hr}$ LC50 value of $93.59 \%(935.9 \mathrm{ml} / \mathrm{L})$. The leachate was found to be high on biological and chemical oxygen demand, conductivity, total dissolved solids, nitrate and sulphate. The findings from this study indicate widespread and unregulated practice of coastal solid waste dumping with potential effects on water quality and biota. The need for improved waste management system in the City of Lagos was discussed. () JASEM
\end{abstract}

http://dx.doi.org/10.4314/jasem/v19i3.21

KEYWORDS: Aquatic Pollution; Waste Management; Environmental Policy; Solid Waste; Waste Recycling

Introduction

Solid waste dumps are common occurrence in third world countries where comprehensive waste management systems are not enforced and limited budgetary allocations exist to tackle this problem. Numerous studies have been conducted focusing on pollution of the Lagos lagoon by various activities ranging from crude oil, industrial effluents, sewage and a wide variety of other pollutants (Ajao, 1996, Amaeze 2014), but limited studies have been carried out on rising trend of solid waste costal dumpsites and its effects on our water bodies. In Nigeria, this is particularly true in coastal areas as reported by Amaeze et al. (2012) in a recent survey detailing the sources of pollution in the Lagos lagoon.

Waste, according to UNEP (2009), is anything that has served its original intended purpose and is being discarded or stored prior to being discarded while solid waste is defined as non-liquid and non-gaseous products of human activities, regarded as being useless (Berkun et al., 2005). In the Lagos lagoon, despite numerous investigations carried out, there is still a dart of knowledge on solid waste pollution and its effect in the water column. Solid waste compositions vary considerably throughout the world and even between dumpsites within the same locality. The composition of solid waste is often a function of the nature of the locality, whether residential, market, commercial or industrial. These solid wastes which are attributed entirely to anthropogenic factors and activities consist of variety ranging from domestic biodegradables, persistent pollutants, and nonpersistent pollutants (Van Veldhuizen and Aragones, 1992).

Third world countries that have not developed efficient means to dispose these waste have left them in the hands of nature. Overland dumps are usually commonly used for waste disposal. This is largely because landfill is the simplest, cheapest and most cost-effective method of disposing of waste (Barrett and Lawler, 1995). Solid waste management in Nigeria is the responsibility of State and Local

\footnotetext{
* Corresponding Author: amaezenh@gmail.com
} 
Government environmental agencies (Ogwueleka, 2009) but the burden of managing fast growing cities in developing countries is often overwhelming. This is coupled with weak or non- existent chain of custody for handling such wastes. In Lagos, one of the means of disposal of solid wastes is by dumping them by the coastline of the Lagoon or Atlantic Ocean. The high population density and lack of regulatory framework has made coastal dumping a normal occurrence.Coastal pollution, and the overexploitation of natural resources, are global problems but are particularly severe in areas of high population density and those adjacent to semi-enclosed and shallow seas (Evans et al., 1995). Coastal dumps may results in leaching of toxicants and release of debris into water resulting the changes in water chemistry (Nubi et al., 2008), loss of aesthetics and sometimes fish kills due to entanglement and asphyxiation by plastic materials (Derraik, 2002).Waste in coastal area deforms beautiful seaside landscape and the slow rate of degradation rate of wastes such as plastic is of environmental concern as well (Rezazadeh et al., 2014).

To this effect an investigative study is required in the Lagos lagoon, in order to determine the extent of the problem of solid waste dumps and their impacts on fishes inhabiting it. This study is designed to provide an update on the sparse literature available and resound the need for sound solid waste management practices to be adopted by the Lagos State Government, other such similar authorities in the country and elsewhere in the world so as to protect valuable aquatic ecosystems.

\section{MATERIALS AND METHODS}

STUDY AREA: The study was carried out along the coastline of the Lagos Lagoon, the largest estuary in Nigeria leading into the Atlantic Ocean. The lagoonis estimated stretch of more than $50 \mathrm{~km}$ long and $13 \mathrm{~km}$ wide, separated from the Atlantic Ocean by long sand split 2 to $5 \mathrm{~km}$ wide, which has swampy margins on the lagoon side (Okusipe 2004). The lagoon consists of estuarine water that is fed majorly in the north by Ogun River, with a host of other smaller rivers as well as tidal creeks. It discharges in the south into the South Atlantic Ocean through the Lagos Harbour. The vastness of the lagoon may easily hide the many shallow places present within the system. The Lagos Lagoon is the ultimate sink of a number of industrial discharges/effluents and run-offs from the surrounding Metropolis and there is often high housing density along the coastline (Amaeze et al. 2012).

Sampling Design: A census count of obvious dump and litter sitesalong the coastline of the lagoon was conducted by visiting each site on a motorized boat. Each site was geo-referenced using hand held GPS device (Fig. 1) and with pictures were taken (Plate 1). A randomly selected dumpsite was sampled for leachates collection for laboratory analyses which comprised of physicochemical characteristics assessment and bioassay using brackish water shrimps, Palaeomonetes africanus. 


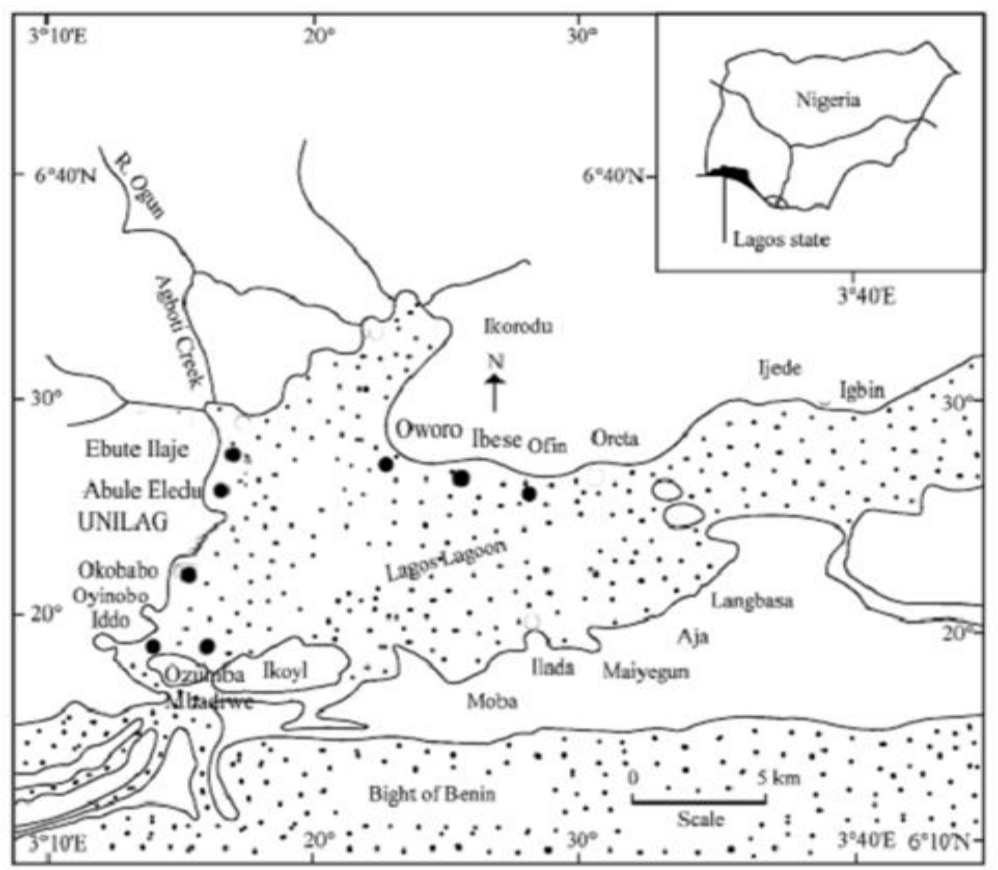

Fig 1: Sampling locations in the Lagos lagoon

Physical Assessment: The physical appearance of the various dumps and litter sites were examined and documented using photographs, size estimates and dumpsite composition. Different human activities causing the dumps were also documented. This process was repeated in all the sampling locations and the results documented qualitatively.

Leachate Collection and assessment of the Physicochemical Characteristics: Leachates with sediments were collected from, Abule eledu dump site, one of the 8 major dumps assessed. Collected leachate were kept in dark plastic containers, transported cool and refrigerated away from sunlight until required for acute toxicity testing.

The collected leachate was assessed for physicochemical parameters which include conductivity, hydrogen ion concentration $(\mathrm{pH})$, total dissolved solid (TDS), chemical oxygen demand (COD), biological oxygen demand (BOD), sulphate (SO4), nitrate (NO4), ammonia (NH3), zinc, lead, cadmium, and nickel using standard methods (APHAAWWA-WEF, 2005).

Test Animal: Description, Collection, and Acclimatization: The organism used for the toxicity test was Palaeomonetes africanus (brackish water shrimps). (Phylum: Arthropoda, Class: Malacostraca, Order: Decapoda, Family: Palaemonidae). The shrimps were collected from the University of Lagos lagoon front, a relatively unpolluted section of the lagoon. They were caught using a hand held net in the evening, at low tide and transported in a container filled with lagoon water to avoid stress or death, due to agitation during transport.

The shrimps were kept in a container half filled with the lagoon water at a stocking density of 250 shrimps per liter. Acclimation of organisms to laboratory conditions was for seven days prior to commencing the test. The shrimp were not fed for $24 \mathrm{hr}$ before test initiation (Reish and Oshida, 1986). Only batches with less than $5 \%$ mortality were employed in the acute toxicity tests.

General Bioassay Procedure; Bioassay Containers: The bioassay containers used were clean plastic buckets, 5 liters in volume.

Range Finding Tests: Several experiments were carried out so as to establish the concentration of the leachate to be employed in definitive test. Tests were carried out in duplicates with control set ups as well.

Preparation of Test Media: A measuring cylinder was used to collect of lagoon water of various volumes into each bioassay container. The lagoon water was inversely proportional to the leachate such that increase in leachate volume translates to decrease in lagoon water measurement. The total solution contained in each test container was 1 litre. Test concentrations were calculated as $\mathrm{ml} / \mathrm{L}$ and percentage $(\%)$. 
Acute toxicity assessment of the sample site leachates on Palaeomonete safricanus:

20 active shrimps per duplicate of similar sizes were exposed to varied concentrations of the test compounds as described below:

Sample site leachates against Palaeomonetes africanus at: $40 \%, 50 \%, 60 \%, 70 \%, 80 \%, 90 \%, 100 \%$ of 1 litre of lagoon water and untreated control.

Mortality was assessed once every $24 \mathrm{hr}$ for 4 days; i.e. at the same hour the test animals were introduced in it the test media for period of $96 \mathrm{hr}$.

Assessment of Quantal Responses in Exposed Shrimps The mortality rate was assessed cumulatively throughout the test period at 24, 48, 72 and $96 \mathrm{hr}$. Shrimps considered dead were those that failed to respond to mechanical stimulation even when touched with forceps. The dead ones were removed from the bioassay containers to prevent contamination.

Statistical Analysis: The dose response data (mortality data) was analyzed by computer based probit analysis using SPSS ${ }^{\circledR}$ version 17. The data were analyzed and presented as follows:

$\mathrm{LC}_{5}=$ lethal concentration that will bring $5 \%$ mortality of the exposed population.

$\mathrm{LC}_{50}=$ median lethal concentration that will bring about 50\% mortality of the exposed population.

$\mathrm{LC}_{95}=$ lethal concentration that will bring about $95 \%$ mortality of the exposed population.

\section{RESULTS AND DISCUSSION}

Dumpsite Census in the Lagos Lagoon: A total of 8 locations harbouring 28 dumpsites were observed in this study (Table 1). Oworonshoki and Ibese recorded the highest number of dumpsites, each with 5 (19\%) active dumpswhile the lowest number of dumpsite (4\%) was observed at the Off Ozumba Mbadiwe study location (Table 1).

Relative Waste Composition: The predominant wastes in the dumpsites include used plastics, domestic refuse, vegetable wastes, municipal wastes, human excrement and wood shavings (Table 2, Plate 1a-h). Specifically, Iddo and Okobaba were characterized by high presence of sugar cane waste and wood shavings respectively (Plate 1d). Abule Eledu, Ebute Ilaje, Oworonshoki, Offin and Ibese were characteristic residential areas, with active and unregulated coastal dump sites which sometimes served as foundation for wooden houses of coastal dwellers (Table 2).

Table 1: Observed dumpsites in coastal Lagos lagoon

\begin{tabular}{lllll}
\hline Study & $\begin{array}{l}\text { Number } \\
\text { Locations }\end{array}$ & of Dumpsites & $\begin{array}{l}\text { Relative } \\
\text { Percentage }\end{array}$ & \multicolumn{2}{l}{ GPS Coordinates } \\
\cline { 4 - 5 } Abule Eledu & 2 & & Long. & Lat. \\
Ebute Ilaje & 3 & $8 \%$ & 3.399 & 6.523 \\
Oworonshoki & 5 & $11 \%$ & 3.406 & 6.530 \\
Ibese & 5 & $19 \%$ & 3.404 & 6.532 \\
Offin & 3 & $19 \%$ & 3.471 & 6.553 \\
Ozumba M. Rd. & 1 & $12 \%$ & 3.501 & 6.538 \\
Iddo & 4 & $4 \%$ & 3.557 & 6.472 \\
Okobaba & 3 & $15 \%$ & 3.382 & 6.437 \\
Total & 28 & $12 \%$ & 3.389 & 6.476 \\
\hline
\end{tabular}

Table 2: Description of study locations, waste categorization and sources

\begin{tabular}{|c|c|c|}
\hline $\mathbf{S} / \mathbf{N}$ & Study Locations & Observation \\
\hline 1 & Abule Eledu & $\begin{array}{l}\text { Located close to university of Lagos, predominantly a residential area with low income earners and } \\
\text { poorly built residential structures. It was observed that local cart pushers used the coast line as a } \\
\text { dumpsite. Wooden barriers to restrict solid waste drifting into the lagoon were present. } \\
\text { Category of wastes: plastics, glass, paper, domestic organics, human waste, and wood shavings. } \\
\text { Source of waste:domestic and municipal waste }\end{array}$ \\
\hline 2 & Ebute Ilaje & $\begin{array}{l}\text { This section is dominated by residential activities and is popular with smoked fish trade that is its } \\
\text { major business in that area. } \\
\text { Wooden barriers to restrict solid waste drifting into the lagoon were present on the coastline. } \\
\text { Category of wastes: plastics, glass, paper, domestic organics, human waste, cloths and wood } \\
\text { shaving. } \\
\text { Source of waste: municipal waste and agricultural waste (spoilt smoked fishes) }\end{array}$ \\
\hline 3 & Oworonshoki & $\begin{array}{l}\text { Residential areas with coastal settlements and dump sites. } \\
\text { Category of wastes: plastics, glass, paper, domestic organics, cloths, and human waste. Wooden } \\
\text { barriers to restrict waste were present. } \\
\text { Source of waste:domestic and municipal wastes. Drifting litters from other areas of the Lagoon. }\end{array}$ \\
\hline 4 & Ibese & $\begin{array}{l}\text { Residential area with no notable businesses found, although dredging was observed in this section } \\
\text { of the lagoon. Wooden barriers to restrict waste were present. } \\
\text { Category of wastes:plastics, glass, paper, vegetable waste, human excrement } \\
\text { Source of waste:domestic and municipal waste }\end{array}$ \\
\hline 5 & Offin & $\begin{array}{l}\text { This is a typical coastal settlement bordered by open dumpsites. No barriers to restrict the spread of } \\
\text { waste into water. }\end{array}$ \\
\hline
\end{tabular}




\begin{tabular}{|c|c|c|}
\hline & & Category of wastes:plastics, glass, paper, vegetable waste, human excrement \\
\hline 6 & $\begin{array}{l}\text { Off Ozumba Mabdiwe, } \\
\text { Victoria Island }\end{array}$ & $\begin{array}{l}\text { This is a high brow residential and commercial area characterized, with well-engineered coast line. } \\
\text { Category of wastes: paper, plastic, packaging materials, vegetable wastes, and waste raffia baskets } \\
\text { Source of waste:Municipal wastes }\end{array}$ \\
\hline 7 & Iddo & $\begin{array}{l}\text { Sugar cane was the dominant waste, but the tyres were found dumped on the lagoon coast. } \\
\text { Category of waste: solid waste dump, sugarcane, and rubber } \\
\text { Source of waste: Sugar cane processing, domestic and municipal waste }\end{array}$ \\
\hline 8 & Okobaba & $\begin{array}{l}\text { Site for receiving logs transported from distant towns to Lagos, sawmilling, dumping and burning of } \\
\text { wood shavings and dumping of refuse. } \\
\text { Category of waste: wood waste, plastics, organic wastes and human excrement } \\
\text { Source of waste:wood processing industry, domestic and municipal waste }\end{array}$ \\
\hline
\end{tabular}

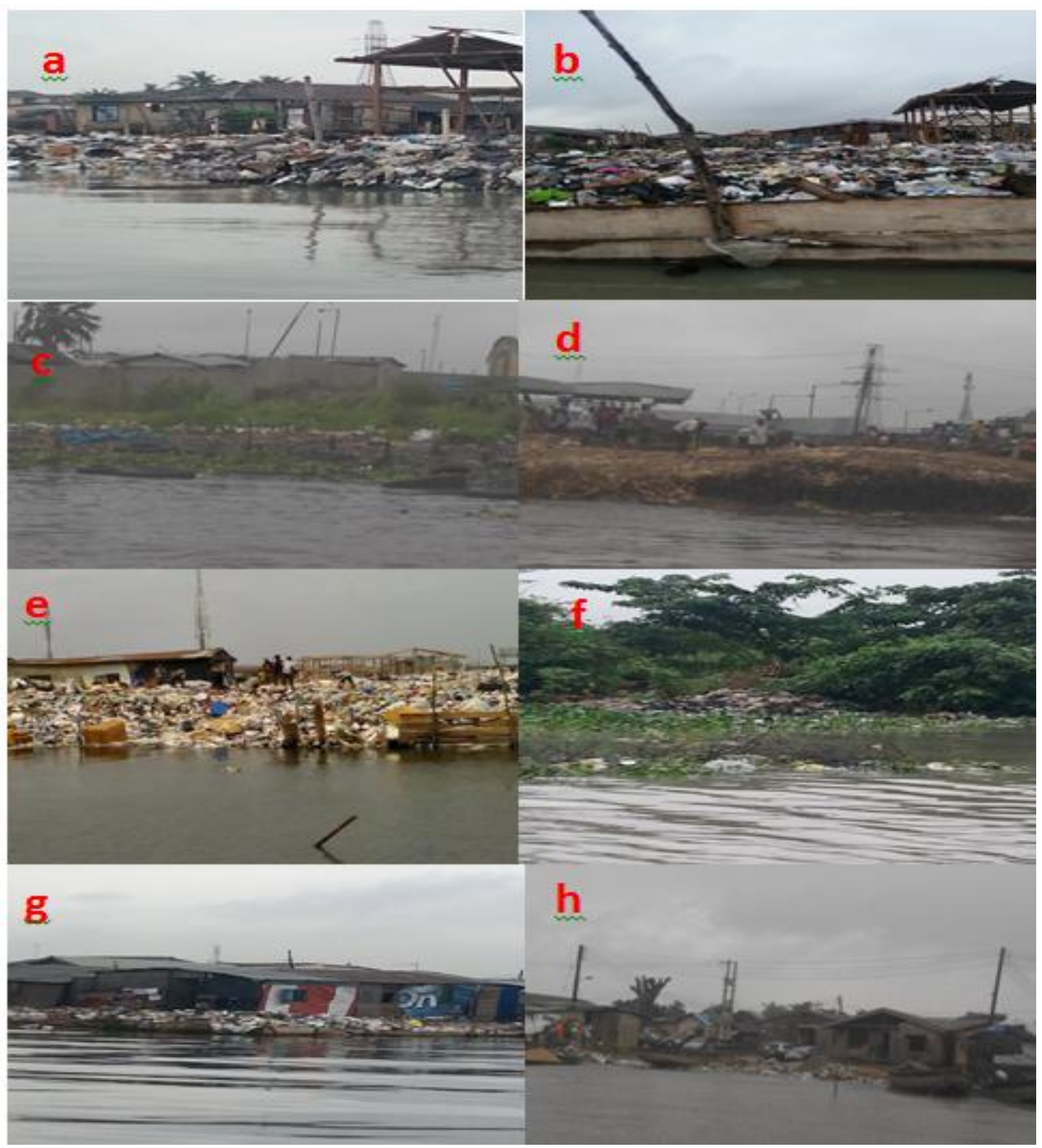


Plate 1(a-h): Some coastal dump site at, a- Abule Eledu without wooden barriers, b- Abule Eldeu with wooden barriers, c- with tyres at Iddo, d- sugar cane dump at Iddo, e- scavengers on a coastal dumpsite in Okobaba, flitter dumpsite in Oworonshoki, g- dumpsite observed close to coastal residents near Ibese jetty and $\mathbf{h}$-dumpsites and litters observed on coast at Offin

Physiochemical Parameters of Dumpsite: Analysis of leachates from one of the major dumpsites (Abule Eledu) showed that $\mathrm{pH}$ was within range of the WHO standard. The biological oxygen demand (BOD) and total dissolved solid (TDS) were above the required standard of WHO. The heavy metals, lead and zinc as well as sulphate were below the limits for marine water. The surface water conductivity was about 4 times the WHO standard. The concentrations of nitrate, ammonia, nickel, cadmium were above the stipulated WHO standard for wastes destined for discharge in water (Table 3).

Table 3: Observed physicochemical characteristics of the leachate sample from Abule Eledu compared against WHO standards

\begin{tabular}{lll}
\hline Parameters & Concentrations & WHO Standards \\
\hline $\mathrm{pH}$ & 6.64 & $6-9$ \\
Conductivity $(\mu \mathrm{S} / \mathrm{cm})$ & 5560 & 1500 \\
Biological oxygen demand $(\mathrm{BOD})(\mu \mathrm{g} / \mathrm{g})$ & 69 & 50 \\
Chemical oxygen demand $(\mathrm{COD})(\mu \mathrm{g} / \mathrm{g})$ & 140 & $\mathrm{NA}$ \\
$\mathrm{TDS}(\mu \mathrm{g} / \mathrm{g})$ & 2810 & 1000 \\
Nitrate $\left(\mathrm{NO}_{3}\right)(\mu \mathrm{g} / \mathrm{g})$ & 40.5 & 5 \\
Ammonia $\left(\mathrm{NH}_{4}\right)(\mu \mathrm{g} / \mathrm{g})$ & 1.5 & 1 \\
Cadmium $(\mathrm{Cd})(\mu \mathrm{g} / \mathrm{g})$ & 0.009 & 0.003 \\
Sulphate $\left(\mathrm{SO}_{4}\right)(\mu \mathrm{g} / \mathrm{g})$ & 22 & 250 \\
Lead $(\mathrm{Pd})(\mu \mathrm{g} / \mathrm{g})$ & 1.809 & 5 \\
Nickel $(\mathrm{Ni})(\mu \mathrm{g} / \mathrm{g})$ & 0.01 & 0.00 \\
Zinc $(\mathrm{Zn})(\mu \mathrm{g} / \mathrm{g})$ & 0.327 & 5 \\
\hline
\end{tabular}

Acute Toxicity of Leachates on Brackish Water Shrimp (Palaeomonetes Africanus)

The results from the acute toxicity studies indicated that no adverse behavioural changes or any mortality was recorded in the control shrimps throughout the test period. Observed behaviour of shrimps exposed to the test chemicals before the eventual death include erratic swimming and restlessness. The Leachate had a considerably low/ moderate acute toxicity. On the basis of the $96 \mathrm{hrs} \mathrm{LC}_{50}$ calculations, $93.59 \%$ of the leachate resulted in $50 \%$ mortality of the shrimps (Table 4).

Table 4: Acute toxicity of the leachates

\begin{tabular}{llllll}
\hline Test compound & $\mathbf{L C}_{\mathbf{5}}$ & $\mathbf{L C}_{\mathbf{5 0}}$ & $\mathbf{L C}_{\mathbf{9 5}}$ & Standard Error & DF \\
\hline Leachates & 20.96 & 93.59 & 166.22 & 0.004 & 5 \\
\hline
\end{tabular}

The emphasis on this survey of the Lagos Lagoon was to assess the solid waste dump and litter sites found along the coastline, which are in constant receipt of domestic, municipal and industrial wastes. These wastes eventually leach into the water or are washed into water and drift far of under tidal action. The ubiquity of solid waste dumps observed in this study in the Lagos lagoon is a course for concern.

The unsustainable practice of coastal dumping of solid waste in the Lagos lagoon is brought to the fore in this study and the findings indicated that it is widespread with minimal regulatory efforts to stop such practices. According to UNESCO (2003), the types of pollutants plaguing marine ecosystems includes sedimentation, agricultural run offs, thermal and light energy, sewage, solid wastes, chemicals, metals, radioactive substances, oil and biological materials. Thus, this finding in the Lagos lagoons conforms to the UNESCO assertions. The dominant solid wastes recorded in most of the dump sites surveyed were plastics which include nylons (polyethylene bags), containers, packaging materials and other plastic products. The dominance of plastics can be attributed to the frequency of use because of their low cost and their non biodegradable nature. This corroborates the findings of (Ajao, 1996; UNEP, 2006) which noted widespread pollution of the Lagos lagoon. Polyethylene products can lead to suffocation of aquatic animals which mistakenly swims into them and when swallowed may result is blockages of tracts and eventually death. Nubi et al. (2008) in their 
study, reported that most of the wastes found in these dumps are persistent (non-biodegradable) in the environment, and continuously leach heavy metal into the water body.

The presence of the solid waste dumps is an indication of unregulated anthropogenic activities in such areas and suggests a general lack of proper waste management service and control. Therefore the use of these open coastal spaces is preferred for its convenience as suggested by (Sankoh et al., 2013). This trend is not unique to this region of Nigeria as it has been a striving trend in the western coast of Africa and other developing countries (Douglas, 1992). Environmental impacts of these coastal dumpsites include nauseating offensive odour, surface metal enrichment, microbial contamination, human health hazard, the possibility of choking and eventually death of many marine animals. Ingestion of plastics, the releases of dangerous toxins and entanglement are often the major problems plaguing marine animals (UNEP, 2006).

The physiochemical analysis of the leachates showed high TDS, with the presence of ammonia, nickel, lead, and cadmium which were above WHO and FEPA standards as employed in Rainbow, (1995) and Amaeze et al. (2012). The high level of solutes from a variety of decomposing and degrading materials may be responsible for the high turbidity reported, which eventually would impact the overall turbidity of the Lagoon. This is especially of concern, given that turbidity is a limiting factor for light penetration and primary productivity in aquatic ecosystems.

However, the relatively low toxicity of the leachate to brackish water shrimps as observed from the bioassay studies may be due to the dilution from mixing with the lagoon surface water. Despite the relatively low acute toxicity, the concern should be on the overall long term effect of continuous exposure to a cocktail of toxicants from the several dumpsites which dot the coastline of this lagoon. These together with other waste sources threatens the integrity of this vital water body.

Conclusion: Our findings indicates that asides from the loss of aesthetic value, these solid wastes find their way to the water and threatens sensitive species with acute toxicity and likely sub lethal effects. Also these dump sites are potential breeding grounds for parasite and pathogens and therefore may be important in the spread of diseases in this region. The decrease in quality of the water body for use in various ways is also notable.
Overall, this study re-emphasizes the pollution status of the Lagos lagoon and advocates for increased regulation and provision of alternatives by the government and relevant agencies to avert the environmental hazard posed by these dump sites.

Due to a combination of factors such as poverty, lack of infrastructure, low level of awareness, inadequate government encouragement through incentives, poor legal instruments and weak law enforcement strategies, the capacity to mange solid waste in Lagos sate remains low. The current efforts of the State government at enlightening the public and encouraging private participation is however noteworthy but efforts needs to be put in place to increase focus on coastal dump sites. This can be achieved via increased sensitization of coastal communities, provision of alternatives and enforcement of extant state laws. When solid waste is well managed the value chain of benefits is considerable

Conflict of interests: The authors affirm that there is not conflict of interest regarding this article.

\section{REFERENCES}

Ajao, EA (1996). Review of the state of pollution of the Lagos lagoon. Nigeria Institute for Oceanography and Marine Research (NIOMR) Technical Paper No. 106.

Amaeze, NH, Egonmwan, RI, Jolaosho, AF, Otitoloju, AA (2012). Coastal Environmental Pollution and Fish Species Diversity in Lagos Lagoon, Nigeria. IJEP 2 (11):8-16.

Amaeze, NH (2014). Endocrine disruption and cytogenotoxicity as indicators of pollution in the Lagos Lagoon. Ph.D Thesis, University of Lagos.

APHA-AWWA-WEF (2005). Standard Methods for the examination of water and wastewater, $21 \mathrm{st}$ edition.

Barrett, A, Lawlor, J (1995). The economics of waste management in Ireland. Economic and Social Research Institute, Dublin.

Berkun, M, Aras, E, Nemlioglu, S (2005). Disposal of solid waste in Istanbul and along the Black Sea coast of Turkey. Waste Manage25: 847-855.

Derraik, JGB (2002). The pollution of the marine environment by plastic debris: a review. Marine Poll Bull 44: 842-852.

Douglas, T (1992). Patterns of land, water and air pollution by waste. In: Newson, M. (Ed.) 
Managing the Human Impact on the Natural Environment John Wiley \& Sons.

Evans, SM, Dawson, M, Day, J, Frid, CCLJ, Gill, ME., Pattisina, LA, Porter, J (1995). Domestic waste and TBT pollution in coastal areas of Ambon Island (Eastern Indonesia). Marine Poll Bull 30(2): 109-115.

Nubi, OA, Ajao, EA, Nubi, AT (2008). Pollution assessment of the impact of coastal activities on Lagos Lagoon, Nigeria Science World Journal 3(2): $83-88$.

Ogwueleka, TC (2009). Municipal Solid Waste Characteristics and Management in Nigeria. Iran. J. Environ. Health Sci. Eng 6 (3):173-180.

Okusipe, OM (2000). Lagos Lagoon coastal profile: Information database for planning theory. Lagos State Environment Report.

Rainbow, PS (1995). Biomonitoring of heavy metal availability in the marine environment. Marine Poll Bull 31(4): 183-192.

Rezazadeh, M, Abdoli, M, Mehrdadi, N, Mousavinezhad, M (2014). Municipal Solid Waste Management in Coastal line of Gilan Province. IJABBR 2 (5): 1638-1649.
Sankoh, PF Yan, X, Tran, Q (2013). Environmental and Health Impact of Solid Waste Disposal in Developing Cities: A Case Study of Granville Brook Dumpsite, Freetown, Sierra Leone. JEP 4: 665-670

UNEP (2006). Marine And Coastal ecosystems And Human Well-Being Synthesis: A synthesis report based on the findings of the Millennium Ecosystem Assessment

UNEP (2009). Developing Integrated Solid waste management Plan. Assessment of Current Waste Management System and Gaps therein.

UNESCO (2003). The integrated strategic design plan for the coastal observations module of the Global Ocean-ographic Observing System. IOC/INF-1183.GOOS Report 125.

Van Veldhuizen, HD, Aragones, N (1992). Ecological impacts of waste disposal in the coastal and marine environment. Waste Management in the Coastal Areas of the ASEAN Region: Roles of Governments, Banking Institutions, Donor Agencies, Private Sector and Communities. 